\title{
Critical Nitrogen Deposition Loads in High-elevation Lakes of the Western US Inferred from Paleolimnological Records
}

\author{
Jasmine E. Saros • David W. Clow • Tamara Blett • \\ Alexander P. Wolfe
}

Received: 23 February 2010 / Accepted: 17 June 2010

(C) Springer Science+Business Media B.V. 2010

\begin{abstract}
Critical loads of nitrogen $(\mathrm{N})$ from atmospheric deposition were determined for alpine lake ecosystems in the western US using fossil diatom assemblages in lake sediment cores. Changes in diatom species over the last century were indicative of $\mathrm{N}$ enrichment in two areas, the eastern Sierra Nevada, starting between 1960 and 1965, and the Greater Yellowstone Ecosystem, starting in 1980. In contrast, no changes in diatom community structure were apparent in lakes of Glacier National Park. To determine critical $\mathrm{N}$ loads that elicited these community changes, we modeled wet nitrogen deposition
\end{abstract}

J. E. Saros $(\bowtie)$

Climate Change Institute, and School of Biology and

Ecology, University of Maine,

Orono, ME 04469, USA

e-mail: jasmine.saros@maine.edu

D. W. Clow

US Geological Survey, Water Resources Discipline, Lakewood, CO 80225, USA

e-mail: dwclow@usgs.gov

T. Blett

National Park Service, Air Resources Division,

Lakewood, CO 80225, USA

e-mail: tamara_blett@nps.gov

\section{A. P. Wolfe}

Department of Earth and Atmospheric Sciences, University of Alberta,

Edmonton, AB, Canada

e-mail: awolfe@ualberta.ca rates for the period in which diatom shifts first occurred in each area using deposition data spanning from 1980 to 2007 . We determined a critical load of $1.4 \mathrm{~kg} \mathrm{~N}$ ha $^{-1}$ year $^{-1}$ wet $\mathrm{N}$ deposition to elicit key nutrient enrichment effects on diatom communities in both the eastern Sierra Nevada and the Greater Yellowstone Ecosystem.

Keywords Critical load - Atmospheric nitrogen deposition · Alpine lake ecosystems · Diatoms

\section{Introduction}

Numerous high-elevation lakes are situated in national parks and wilderness areas across the western US. These lakes are important resources on these protected federal lands as they are highly valued for their remarkable water clarity and trout fisheries. The watersheds of many of these lakes have experienced little land use change, and as a result, these lakes tend to have low phytoplankton productivity. However, during the last century, rates of atmospheric nitrogen $(\mathrm{N})$ deposition have increased across this area with regionally variable patterns (Fenn et al. 2003; Nanus et al. 2003), threatening the water quality, transparency, and biological integrity of these remote lakes. Although $\mathrm{N}$ deposition rates are lower in many parts of the western US compared to the east (Holland et al. 2005), western high elevation lakes are often $\mathrm{N}$-limited or co-limited by $\mathrm{N}$ and phosphorus (P; Morris and Lewis 1988; 
Smith et al. 2003; Lewis and Wurtsbaugh 2008). This renders them susceptible to the enrichment effects of $\mathrm{N}$ deposition, which occur at lower $\mathrm{N}$ concentrations than acidification effects (Baron 2006).

Early ecological effects of $\mathrm{N}$ deposition on western alpine lakes can be assessed using changes in diatom community structure. Diatoms are a class of microscopic algae that are sensitive to limnological changes and have cell walls that are frequently well preserved in lake sediments. Shifts in diatom community composition provide early indications of ecological perturbations, whether by acidification (Charles et al. 1990), eutrophication (Hall et al. 1997), or climate change (Smol et al. 2005). Because of the documented sensitivity of diatoms to environmental change, they have been used to define critical loads of acidity (Battarbee et al. 1996) and nitrogen enrichment (Baron 2006) to surface waters, with the critical load defined as the threshold below which observable ecological effects do not occur (Porter et al. 2005).

Changes in sedimentary diatom assemblages relating to enhanced atmospheric $\mathrm{N}$ deposition have been documented in the Colorado Front Range (Wolfe et al. 2001) and the Absaroka-Beartooth Wilderness Area (part of the Greater Yellowstone Ecosystem; Saros et al. 2003). Specifically, increases in two diatom taxa, Asterionella formosa and Fragilaria crotonensis, are used as indicators of $\mathrm{N}$ enrichment in N-limited lakes, as Saros et al. (2005) demonstrated that these two species respond positively to moderate $\mathrm{N}$ enrichment in alpine lakes. Baron (2006) used diatom fossil records from the Colorado Front Range to determine a critical $\mathrm{N}$ load for lakes of Rocky Mountain National Park, which are situated in a relatively high $\mathrm{N}$ deposition area of the West (currently receiving approximately $3 \mathrm{~kg} \mathrm{~N} \mathrm{ha}^{-1}$ year $^{-1}$ total inorganic wet deposition; NADP 2009). Increases in $A$. formosa and $F$. crotonensis first occurred between 1950 and 1964 in lakes of this area (Wolfe et al. 2001). Hindcasting total wet inorganic N deposition back to that time period, Baron (2006) inferred a critical load of $1.5 \mathrm{~kg} \mathrm{~N}^{-1}$ year $^{-1}$ wet deposition to elicit ecological change in these lakes.

Critical loads of sulfur and nitrogen deposition have been widely defined for European surface waters (Henriksen et al. 1992; Curtis et al. 2000; Curtis et al. 2005). Despite the rapid ecological changes occurring across high-elevation lakes of the western US, only one critical $\mathrm{N}$ load value has been defined for this large region, and is based on a relatively small geographic area, Rocky Mountain National Park (Fig. 1). The goal of this study is to enhance understanding about the geographic extent and threshold levels that may trigger diatom responses at low $\mathrm{N}$ levels elsewhere in the western US. To accomplish this, we quantified critical $\mathrm{N}$ loads in three class I wilderness areas across the western US that receive lower rates of $\mathrm{N}$ deposition compared to Rocky Mountain National Park: the eastern Sierra Nevada mountains (ESN), the Greater Yellowstone Ecosystem (GYE), and Glacier National Park (GNP; Fig. 1). These sites were chosen due to differences in total wet inorganic $\mathrm{N}$ deposition rates. The NADP site in the western Sierra Nevada area currently receives approximately $2 \mathrm{~kg} \mathrm{ha}^{-1}$ year $^{-1}$ of total wet inorganic $\mathrm{N}$ deposition, although rates were as high as $4 \mathrm{~kg} \mathrm{ha}^{-1}$ year $^{-1}$ in the early 1990s (NADP 2009). In contrast, total wet inorganic $\mathrm{N}$ deposition is $1.5 \mathrm{~kg} \mathrm{ha}^{-1}$ year in GNP (range of $0.5-1.5 \mathrm{~kg} \mathrm{ha}^{-1}$ year $^{-1}$ between 1980 and 2006) and $1.0 \mathrm{~kg} \mathrm{ha}^{-1}$ year $^{-1}$ in the GYE (range of $0.5-1.1 \mathrm{~kg} \mathrm{ha}^{-1}$ year $^{-1}$ between 1980 and 2006). We investigated (1) whether other regions of the western US had experienced similar shifts in Nresponsive diatom taxa; and if so (2) whether the shifts were contemporaneous with those observed in Rocky Mountain National Park (1950-1964) or occurred at similar $\mathrm{N}$ deposition levels. Using the same approach as Baron (2006), we examined sedimentary diatom profiles from two lakes in each area (Table 1), and determined total wet inorganic $\mathrm{N}$ deposition rates at the time of key diatom shifts to infer critical $\mathrm{N}$ loads for these regions.

\section{Methods}

Sediment cores were collected from the deepest point in each lake using a gravity corer. The cores from the two lakes in GNP, Old Man and Snyder, were collected as part of the Western Airborne Contaminants Assessment Project (WACAP) study (Landers et al. 2008). These lakes were considered suitable for this study because, unlike many lakes in GNP, they do not receive glacial meltwaters, which strongly affect $\mathrm{N}$ concentrations in lakes (Saros et al. 2010). The lakes from the GYE are located in the Shoshone National Forest (Wyoming), while those in the ESN are in the Inyo National Forest (California). Both the 
Fig. 1 Map of study regions in the western US. Lakes in the eastern Sierra Nevada mountains are in the Inyo National Forest (California), while those in the central Rockies are located in the Beartooth Mountain Range, which is part of the Greater Yellowstone Ecosystem. Lakes in the northern Rockies are located in Glacier National Park

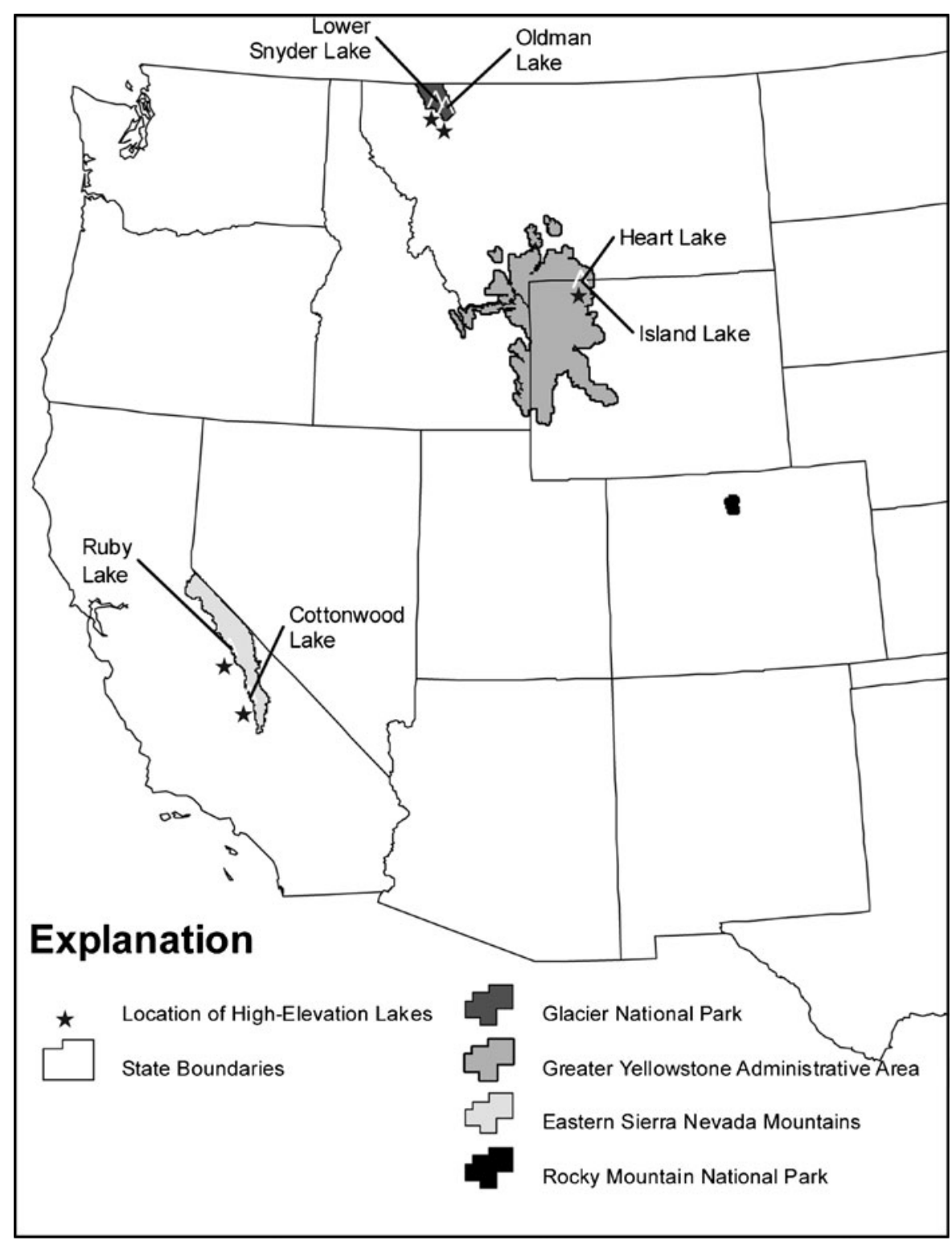

GYE (Saros et al. 2003; Saros et al. 2005) and ESN (Whiting et al. 1989; Melack et al. 1998) lakes have been part of ongoing research on the effects of $\mathrm{N}$ deposition on lakes in these regions. We collected the GYE cores in 2001 and the ESN cores in 2007. The chronology of sediments was based on down-core ${ }^{210} \mathrm{~Pb}$ activities measured by alpha spectroscopy (modified from Eakins and Morrison (1978)), and dates determined according to the constant flux/ constant sedimentation rate (CF/CSR) model (Oldfield and Appleby 1984).

Diatom slides were prepared from digested $(30 \%$ $\mathrm{H}_{2} \mathrm{O}_{2}$ ) sediment samples. The processed samples were settled onto coverslips and mounted onto slides with Naphrax ${ }^{\circledR}$. A minimum of 300 valves per slide was counted under oil immersion on a Nikon E600 Eclipse microscope with differential interference contrast under oil immersion at $\times 600$ magnification. Diatom taxonomy was based primarily on Krammer and Lange-Bertalot (1986-1991) and Camburn and Charles (2000).

While we quantified all diatom taxa in the sediment cores, we relied on changes in two indicator diatom taxa, A. formosa and F. crotonensis, as markers of enhanced $\mathrm{N}$ deposition in western alpine lakes. In-lake batch culture experiments have revealed 
Table 1 Location and key characteristics of high-elevation lakes included in this study

\begin{tabular}{|c|c|c|c|c|c|c|c|c|c|c|c|}
\hline Region & Lake & $\begin{array}{l}\text { Latitude } \\
\left({ }^{\circ} \mathrm{N}\right)\end{array}$ & $\begin{array}{l}\text { Longitude } \\
\left({ }^{\circ} \mathrm{W}\right)\end{array}$ & $\begin{array}{l}\text { Elevation } \\
\text { (m a.s.1.) }\end{array}$ & $\begin{array}{l}\text { Maximum } \\
\text { depth } \\
\text { (m) }\end{array}$ & $\begin{array}{l}\text { Lake } \\
\text { surface } \\
\text { area (ha) }\end{array}$ & $\mathrm{pH}$ & $\begin{array}{l}\text { ANC } \\
\left(\text { ueq } L^{-1}\right)\end{array}$ & $\begin{array}{l}\text { Nitrate } \\
\left.(\text { ug L L })^{-1}\right)\end{array}$ & $\begin{array}{l}\text { Nearest } \\
\text { NADP site }\end{array}$ & Source \\
\hline \multirow[t]{2}{*}{ GYE } & Island & 44.9486 & -109.5427 & 2,901 & 31 & 60.7 & 7.1 & 116 & 4 & WY08 & Saros et al. 2005 \\
\hline & Heart & 44.9830 & -109.5391 & 3,162 & 46 & 16.6 & 7.3 & NA & 1 & & \\
\hline \multirow[t]{2}{*}{ GNP } & Old Man & 48.5122 & -113.4607 & 2,215 & 17 & 18.2 & 8.2 & 1574 & $<1$ & MT05 & Landers et al. 2008 \\
\hline & Snyder & 48.6306 & -113.7939 & 1,585 & 3.5 & 2.6 & 6.4 & 162 & 20 & & \\
\hline \multirow[t]{2}{*}{ ESN } & Cottonwood \#5 & 36.4989 & -118.2289 & 3,729 & 35 & 10.7 & 7.2 & 110 & $<1$ & CA75 & Whiting et al. 1989 \\
\hline & Ruby & 37.4139 & -118.7708 & 3,667 & 32 & 14.5 & 6.4 & 23 & 5 & & \\
\hline
\end{tabular}

Study areas include the Greater Yellowstone Ecosystem (GYE), Glacier National Park (GNP), and the eastern Sierra Nevada (ESN). The nearest collection site in the National Atmospheric Deposition Program (NADP) is indicated for each area, as well as sources for water chemistry data ( $A N C$ acid neutralizing capacity) for the lakes

positive responses to $\mathrm{N}$ enrichment for both of these species (Saros et al. 2005). Hence, the timing of increases in the relative abundances of these two taxa was used as an indicator of the timeframe in which $\mathrm{N}$ deposition rates first exceeded a critical load.

We adopted the approach of Baron (2006) to infer $\mathrm{N}$ deposition rates during the timeframe in which target diatom taxa first increased. For each area, an exponential equation was fit to the total wet inorganic $\mathrm{N}$ deposition data from 1980 to 2007 (i.e., the total period of record) from the nearest NADP site (Table 1). Baron (2006) found exponential trajectories for historical emissions trends spanning 11 western states (Washington, Oregon, California, Idaho, Nevada, Utah, Arizona, Montana, Wyoming, Colorado, and New Mexico). The exponential equation was solved for the timeframe in which the percent abundance of the indicator diatom taxa first doubled above background levels and exceeded 5\% of the total diatom assemblage in each core. If these years differed between the two cores in each area, N deposition values were inferred for the time span between the two cores and averaged to generate a critical load value. In cases where the years in which shifts in the target diatom taxa first occurred after 1980, recorded deposition values at the nearest NADP site were used, with corrections as described below.

The NADP site in the Greater Yellowstone Ecosystem (site WY08) is situated at an elevation of only $1,912 \mathrm{~m}$, whereas the two study lakes in this region are situated at $2,900 \mathrm{~m}$ or higher (Table 1). To account for deposition differences due to elevation, we compared 1993-2006 average total wet inorganic $\mathrm{N}$ deposition data from the NADP site to modeled average annual wet nitrate deposition values for the locations of the cored lakes (Nanus et al. 2003). We calculated a ratio of deposition at the core sites to that at the NADP site, and multiplied the NADP data between 1980 and 2007 by this ratio. An exponential equation was fit to these adjusted data, and, to determine a critical load, the equation was solved for the time frame in which the indicator diatom taxa increased in the sediment cores.

\section{Results}

Complete diatom profiles for one lake in each region are depicted in Figs. 2, 3, and 4; a summary of changes in the indicator taxa for the remaining three cores is provided in Fig. 5. In the ESN lakes, $A$. formosa and $F$. crotonensis increased in relative abundances starting between 1960 and 1965 across the two study lakes (Figs. 2, 5a). The remainder of the diatom assemblages were dominated by typical alpine taxa routinely found in dilute, nutrient-poor waters, including various small Fragilariaceae and Achnanthes species; their relative abundances declined as those of $A$. formosa and $F$. crotonensis increased.

In the GYE lakes, the increases in A. formosa generally occurred after 1980 (Figs. 3, 5b), again with the relative abundances of typical alpine nutrient-poor taxa declining. Before 1980 in Heart Lake (Fig. 3), A. formosa comprised less than $5 \%$ of diatom assemblages. Starting in 1980, this species gradually increased in abundance in this core, from $6 \%$ in 1980 to $25 \%$ at the surface of the core. A. formosa is present at low percentages $(<10 \%)$ throughout the 
Fig. 2 Sedimentary diatom profile from Ruby Lake (eastern Sierra Nevada), showing the percent relative abundance of each diatom taxon with respect to depth in the core. The ${ }^{210} \mathrm{~Pb}$-inferred dates are indicated on right side of the plot. Year marked in bold is the time period of key diatom changes

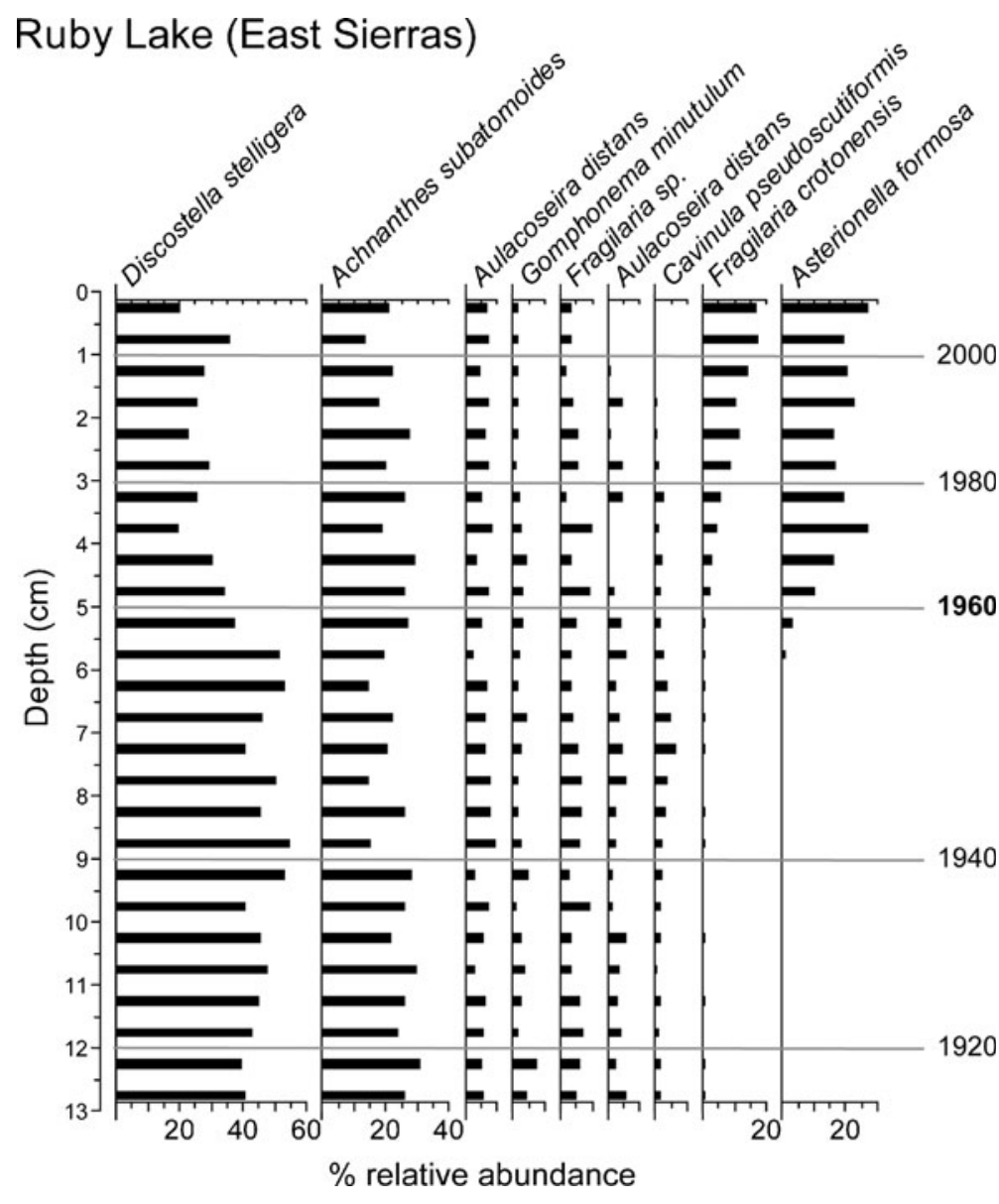

Island Lake core (Fig. 5b) until 1980 when it increases to $20 \%$ or more of the diatom assemblage.

In the GNP lakes, although the $\mathrm{N}$ indicator taxon $F$. crotonensis is present, it did not increase in either of the two cored lakes over the last century (Figs. 4, 5c); hence, a critical load was not determined for this area.

For the ESN, the exponential equation of year compared to total wet inorganic $\mathrm{N}$ deposition was:

$y=\left(2 \times 10^{-15}\right) e^{0.0174 x}$

where, $x=$ year and $y=$ total wet inorganic $\mathrm{N}$ deposition $\left(r^{2}=0.105\right.$; Fig. 6a). Solving for each year between 1960 and 1965, an average $\mathrm{N}$ deposition value of $1.4 \mathrm{~kg} \mathrm{ha}^{-1}$ year $^{-1}$ (standard deviation (SD) of $0.04 \mathrm{~kg} \mathrm{ha}^{-1}$ year $^{-1}$ ) was obtained for that period.

In the GYE, average wet nitrate deposition values from 1993 to 2006, calculated from the approach of Nanus et al. (2003) for the coordinates of the cored lakes, was $1.8 \mathrm{~kg} \mathrm{ha}^{-1}$ year $^{-1}$, while average total wet inorganic $\mathrm{N}$ deposition for the same period from the
NADP site was $1.0 \mathrm{~kg} \mathrm{ha}^{-1}$ year $^{-1}$. We adjusted NADP data using the ratio of $1.8 / 1.0$, and the resulting exponential equation for adjusted data from 1980 to 2007 was:

$y=\left(1 \times 10^{-10}\right) e^{0.0118 x}$

where, $x=$ year and $y=$ total nitrate deposition $\left(r^{2}=\right.$ 0.158; Fig. 6b). Solving for 1978-1983, to bracket the observed 1980 species shifts in the two cored lakes, results in a critical load of $1.4 \mathrm{~kg} \mathrm{~N} \mathrm{ha}^{-1}$ year $^{-1}$ wet deposition (SD of $0.03 \mathrm{~kg} \mathrm{ha}^{-1}$ year $^{-1}$ ).

\section{Discussion}

Paleolimnological records indicated a critical load of $1.4 \mathrm{~kg} \mathrm{~N} \mathrm{ha}{ }^{-1}$ year $^{-1}$ wet deposition to elicit key diatom changes in both the eastern Sierra Nevada and the Greater Yellowstone Ecosystem, despite considerable differences in $\mathrm{N}$ deposition rates between the two 
Fig. 3 As for Fig. 2, but for Heart Lake (Greater Yellowstone Ecosystem)

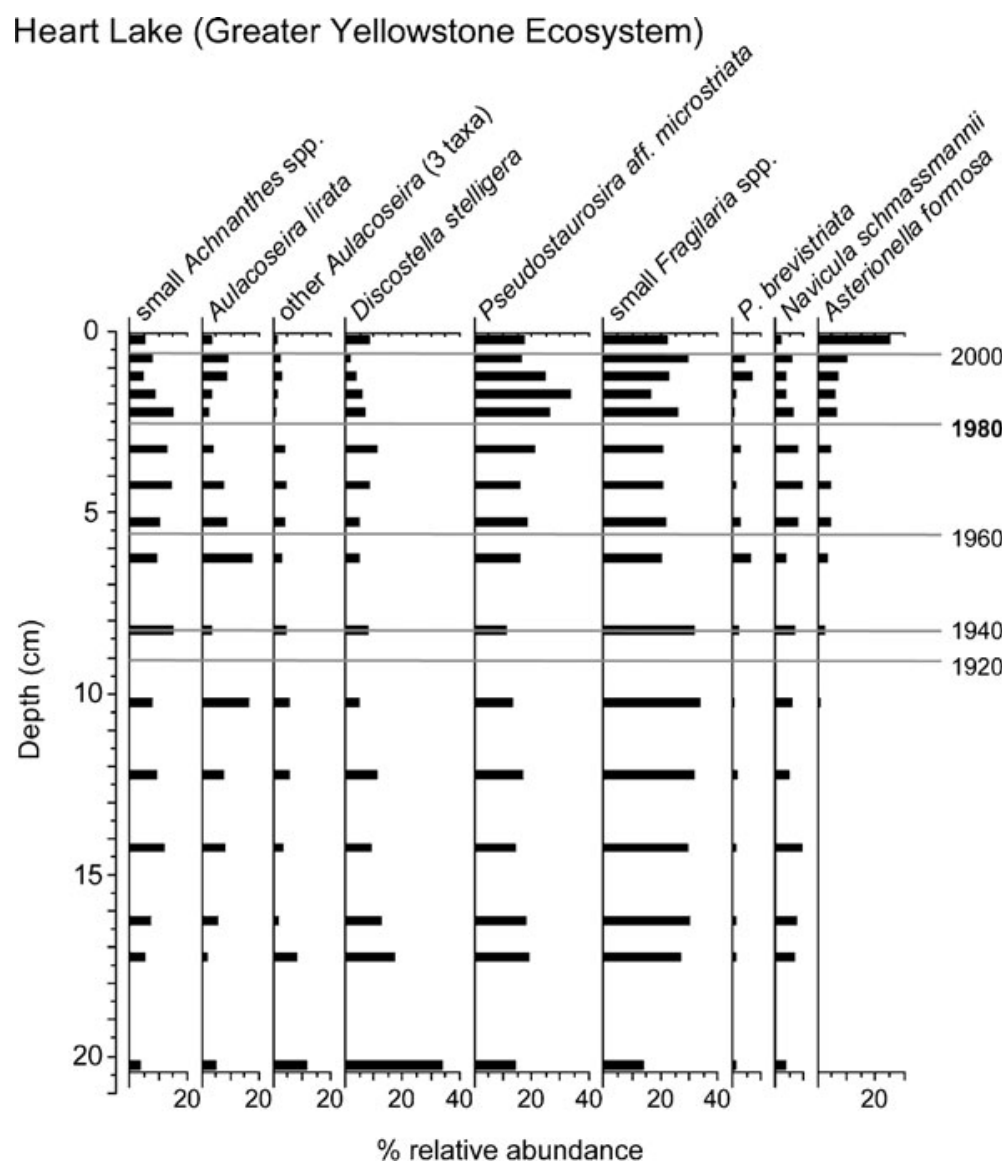

Old Man Lake (Glacier National Park)

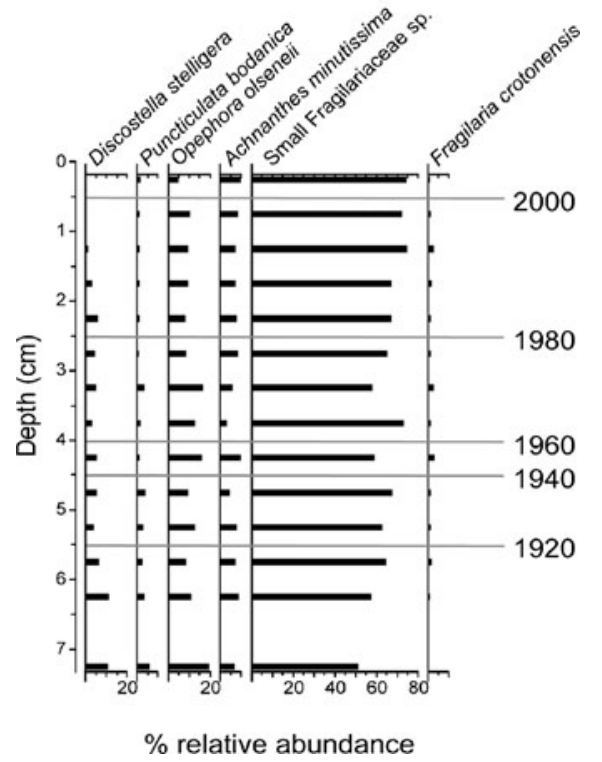

Fig. 4 As for Fig. 2, but for Old Man Lake (Glacier National Park) regions and in the timing of diatom changes. This value also closely matches that determined independently for Rocky Mountain National Park by Baron (2006) of $1.5 \mathrm{~kg} \mathrm{~N} \mathrm{ha}^{-1}$ year $^{-1}$ wet deposition, suggesting that an ecological threshold of 1.4-1.5 kg $\mathrm{N}$ ha ${ }^{-1}$ year $^{-1}$ wet deposition might be broadly applicable across high-elevation lakes of the western US that are N-limited. Nutrient limitation patterns, however, are still unclear in many alpine regions, suggesting the need for clarification of these patterns in broader assessments of the sensitivity of highelevation lakes to $\mathrm{N}$ deposition.

The two key diatom species used as indicators in this study respond strongly to moderate $\mathrm{N}$ enrichment (Saros et al. 2005). Other factors, such as acidification, fish stocking, and climate change, can also influence diatom community structure in alpine lakes, but the key changes in diatom profiles that we used across the three study areas are primarily indicative of $\mathrm{N}$ deposition in the investigated lakes. The same changes in diatom community structure occurred 
Fig. 5 Sedimentary profiles of two key indicator diatom species, $A$. formosa and $F$. crotonensis, in one additional lake from each study site: a Cottonwood \#5 (eastern Sierras); b Island Lake (Greater Yellowstone Ecosystem); c Snyder Lake (Glacier National Park). The ${ }^{210} \mathrm{~Pb}$-inferred dates are indicated on right side of each plot

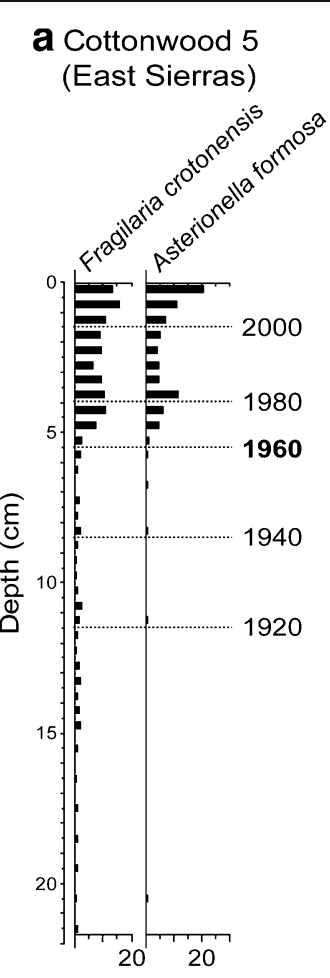

C Snyder Lake (Glacier NP)
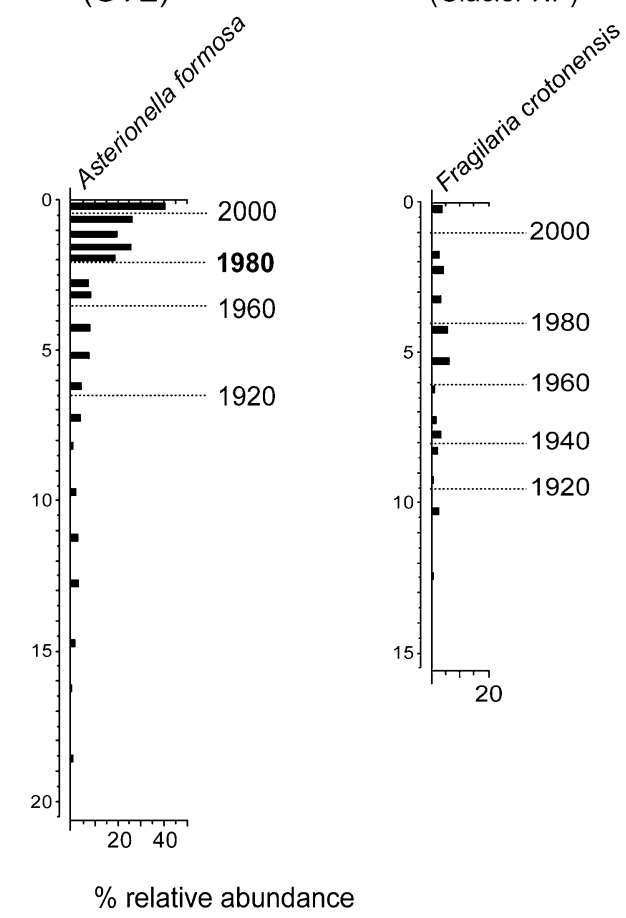

across both ESN lakes, which have fairly different acid-neutralizing capacities (ANC; Table 1), and no changes were apparent in either of the GNP lakes, which also have fairly different ANC. In a high N deposition region of the Colorado Front Range, Wolfe et al. (2003) found similar changes in diatom community structure to those reported here, and noted that these species shifts are not indicative of $\mathrm{pH}$ decline. Fish stocking started in both GYE lakes in the 1930s, yet notable diatom changes did not occur until 1980 in this area. Climate change can also lead to shifts in diatom taxa. Discostella stelligera (Cleve and Grunow) Houk and Klee is a key species associated with changes in water column stability; increases in the relative abundance of this species in recent decades in Arctic, alpine, and temperate lakes have been attributed to warming (Smol et al. 2005; Rühland et al. 2008; Winder et al. 2009). The changes in diatom communities in this study are not consistent with those predicted if warming was the primary driver of these changes, as the relative abundances of taxa such as D. stelligera have declined or remained unchanged. D. stelligera was abundant earlier in the twentieth century in at least one lake from each of the three study areas: Ruby, Heart, Island, and Old Man.
It declined in relative abundance in Ruby, Heart, and Island when $A$. formosa increased in abundance, and remained at low percentages during the twentieth century in Old Man Lake, in which the relative abundance of the $\mathrm{N}$ indicator species (F. crotonensis) did not increase. Pederson et al. (2009) demonstrated that ecologically important temperature thresholds have been exceeded in GNP over the last century, yet the diatom profiles of the two study lakes from that area did not indicate any changes over that time frame. While we recognize that multiple drivers influence the ecology of alpine lakes, the decline or lack of change in the relative abundance of $D$. stelligera in these lakes is not consistent with warming as the primary driver of recent changes in key diatom taxa in the investigated lakes.

The N-enrichment indicator taxon F. crotonensis was present in both GNP lakes but did not increase in the sediment record of either lake. As mentioned above, the two lakes from this area, Old Man and Snyder, were part of the WACAP study (Landers et al. 2008). Water quality data from the WACAP study indicate that DIN/TP values for these lakes are 18.2 and 11.2, respectively. Based on Bergström (2010), this suggests that these lakes, like many in the GNP 


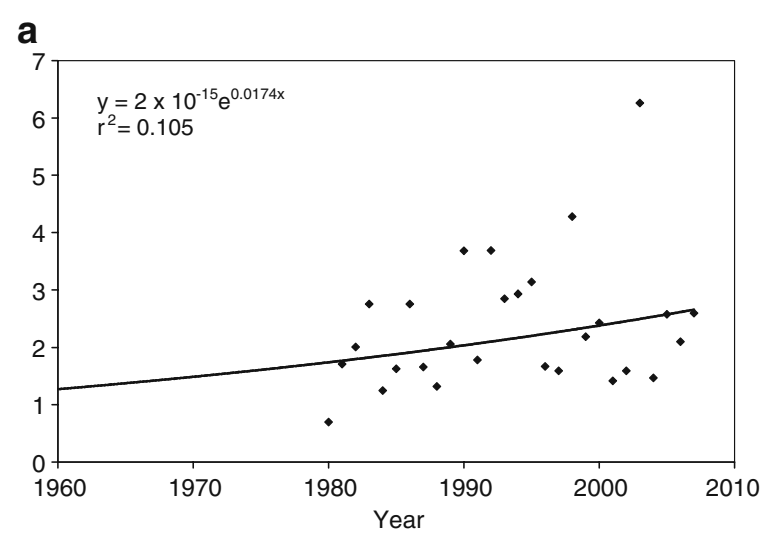

b

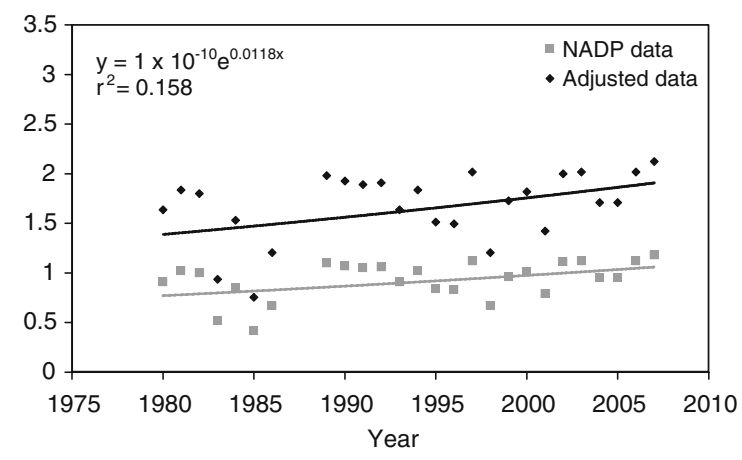

Fig. 6 Exponential relationship between annual total inorganic nitrogen deposition and time for a National Atmospheric Deposition Program (NADP) station CA75, located on the western slope of the Sierra Nevada, California; b NADP station WY08, indicated by squares, and inferred rates adjusted for elevation (as described in the text) indicated by diamonds

area (Saros, unpublished data), are phosphorus limited and hence unlikely to respond to the enrichment effects of N. In addition, these two lakes are shallower than the four lakes from the other regions, potentially leading them to respond differently, if at all, to changes in $\mathrm{N}$ deposition. Owing to carbonate bedrock, these lakes also have relatively high alkalinity compared to other high-elevation lakes of the western US (Landers et al. 1987; Landers et al. 2008), suggesting that many of the lakes of GNP are also likely resilient to acidification effects of sustained $\mathrm{N}$ deposition (Nanus et al. 2009).

The sediment cores from the Sierra Nevada were from lakes on the east slope of the range, whereas NADP site CA75 is located on the west slope. In a comparison of trends in wet $\mathrm{N}$ deposition during the early 1990s at sites from the west and east sides of the Sierras, Melack et al. (1998) concluded that patterns are similar, suggesting that the west side wet deposition data are appropriate for this study. A key difference between the two sides of the range, however, occurs with dry deposition rates (Jim Sickman, University of California, Riverside, personal communication), hence extrapolating the approach here to determine critical dry deposition loads would not be appropriate.

While the critical loads determined here focus on wet deposition values, it should be noted that the percent of total $\mathrm{N}$ deposition comprised of dry deposition differs between the Sierra Nevada and the GYE. In the Sierra Nevada, dry deposition can contribute about half of the total $\mathrm{N}$ deposition on the west side, whereas in the GYE, it only contributes about 15\% (CASTNET 1997-2004). The capacity to include dry deposition values in future critical loads work would provide a more complete assessment of $\mathrm{N}$ deposition effects.

Critical $\mathrm{N}$ loads based on the response of terrestrial plants and lichens in the western US range from 3.1 to $10 \mathrm{~kg} \mathrm{~N} \mathrm{ha}^{-1}$ year $^{-1}$ for community shifts to occur (Bowman et al. 2006; Fenn et al. 2008). Given the high sensitivity and rapid response of diatom community structure to environmental change, diatom community changes occur at much lower $\mathrm{N}$ values than those for terrestrial plants, and changes in these aquatic communities can serve as early warning signs of potential ecosystem change across a region. As such, the critical loads established in this study can be deemed widely protective across high-elevation ecosystems, and may alleviate the recent concern raised by Schlesinger (2009) that the use of thresholds in establishing protective legislation may not adequately prevent ecosystem degradation.

\section{Conclusions}

We determined a critical load of $1.4 \mathrm{~kg} \mathrm{~N} \mathrm{ha}^{-1}$ year $^{-1}$ wet deposition to elicit key nutrient enrichment effects on diatom communities in both the eastern Sierra Nevada and the Greater Yellowstone Ecosystem. Although $\mathrm{N}$ deposition rates are at least this high in Glacier National Park, diatom communities in the two lakes examined there were unchanged over the last century, likely because these lakes are primarily $\mathrm{P}$ limited. With their short generation times, diatom communities respond rapidly to environmental change, making them excellent sentinels of pending, 
broader-scale changes across ecosystems in response to disturbance. This suggests that the use of critical N loads based on the response of diatom community structure may be more broadly protective across ecosystems.

Acknowledgments We thank Dixon Landers for providing sediment samples from the GNP lakes, and for sharing the age models for these cores. Courtney Wigdahl counted the diatoms in the GNP and ESN cores, and assisted with core collection in the eastern Sierras. Data from Mark Whiting, posted on the Diatom Paleolimnology Data Cooperative (http://diatom. acnatsci.org/dpdc/), were helpful in determining our coring sites in the ESN. Leora Nanus provided information on elevation-adjusted $\mathrm{N}$ deposition values for the GYE. Funding for this project was provided by the Air Resources Division of the National Park Service of the US, as well as the US National Science Foundation (DEB-0089600 and DEB-0734277).

\section{References}

Baron, J. (2006). Hindcasting nitrogen deposition to determine an ecological critical load. Ecological Applications, 16, 433-439.

Battarbee, R. W., Allott, T. E. H., Juggins, S., Kreiser, A. M., Curtis, C., \& Harriman, R. (1996). Critical loads of acidity to surface waters: an empirical diatom-based paleolimnological model. Ambio, 25, 366-369.

Bergström, A. K. (2010). The use of TN:TP and DIN:TP ratios as indicators for phytoplankton nutrient limitation in oligotrophic lakes affected by $\mathrm{N}$ deposition. Aquatic Science. doi:10.1007/s00027-010-0132-0.

Bowman, W. D., Gartner, J. R., Holland, K., \& Wiedermann, M. (2006). Nitrogen critical loads for alpine vegetation and terrestrial ecosystem response: are we there yet? Ecological Applications, 16, 1183-1193.

Camburn, K. E. \& Charles, D. F. (2000). Diatoms of lowalkalinity lakes in the northeastern United States. Acad. Natl. Sci. Phila. Spec. Publ. 18.

Charles, D. F., Binford, M. W., Furlong, E. T., Hites, R. A., Mitchell, M. J., Norton, S. A., et al. (1990). Paleoecological investigation of recent lake acidification in the Adirondack Mountains, N.Y. Journal of Paleolimnology, 3, 195-241.

Clean Air Status and Trends Network (CASTNET), 1997-2004. (http://www.epa.gov/castnet).

Curtis, C., Allott, T., Hall, J., Harriman, R., Helliwell, R., Hughes, M., et al. (2000). Critical loads of sulphur and nitrogen for freshwaters in Great Britain and assessment of deposition reduction requirements with the First-Order Acidity Balance (FAB) model. Hydrology and Earth System Sciences, 4, 125-140.

Curtis, C., Botev, I., Camarero, L., Catalan, J., Cogalniceanu, D., Hughes, M., et al. (2005). Acidification in European mountain lake districts: a regional assessment of critical load exceedance. Aquatic Sciences-Research Across Boundaries, 67, 237-251.

Eakins, J. D., \& Morrison, R. T. (1978). A new procedure for the determination of lead-210 in lake and marine sedi- ments. The International Journal of Applied Radiation and Isotopes, 29, 531-536.

Fenn, M. E., Haeuber, R., Tonnesen, G. S., Baron, J. S., Grossman-Clarke, S., Hope, D., et al. (2003). Nitrogen emissions, deposition, and monitoring in the western United States. Bioscience, 53, 391-403.

Fenn, M. E., Jovan, S., Yuan, F., Geiser, L., Meixner, T., \& Gimeno, B. S. (2008). Empirical and simulated critical loads for nitrogen deposition in California mixed conifer forests. Environmental Pollution, 155, 492-511.

Hall, R. I., Leavitt, P. R., Smol, J. P., \& Zirnhelt, N. (1997). Comparison of diatoms, fossil pigments and historical records as measures of lake eutrophication. Freshwater Biology, 38, 401-417.

Henriksen, A., Kimiri, J., Posch, M., \& Wilander, A. (1992). Critical loads of acidity: Nordic surface waters. Ambio, 21, 356-363.

Holland, E. A., Braswell, B. H., Sulzman, J., \& Lamarque, J. (2005). Nitrogen deposition onto the United States and western Europe: synthesis of observations and models. Ecological Applications, 15, 38-57.

Krammer, K. \& Lange-Bertalot, H. (1986-1991). Susswasserflora von Mitteleuropa. Bacilloriophyceae. Stuttgart: Gustav Fischer, Volumes I-IV.

Landers, D. H., Eilers, J. M., Brakke, D. F., Overton, W. S., Kellar, P. E., Silverstein, M. E., et al. (1987). Western lake survey, phase 2, Characteristics of lakes in western United States (Vol. 1, Population descriptions and physicochemical relationships, EPA-600/3-86/054a). Washington, D. C: US Environ. Prot. Agency.

Landers, D. H., Simonich, S. L., Jaffe, D. A., Geiser, L. H., Campbell, D. H., Schwindt, A. R., Schreck, C. B., Kent, M. L., Hafner, W. D., Taylor, H. E., Hageman, K. J., Usenko, S., Ackerman, L. K., Schrlau, J. E., Rose, N. L., Blett, T. F., \& Erway, M. M. (2008). The Fate, Transport, and Ecological Impacts of Airborne Contaminants in Western National Parks (USA). EPA/600/R-07/138. U.S. Environmental Protection Agency, Office of Research and Development, NHEERL, Western Ecology Division, Corvallis, Oregon.

Lewis, W. M., Jr., \& Wurtsbaugh, W. A. (2008). Control of lacustrine phytoplankton by nutrients: erosion of the phosphorus paradigm. International Review of Hydrobiology, 93, 446- 465.

Melack, J. M., Sickman, J. O., \& Leydecker, L. (1998). Comparative analyses of high-altitude lakes and catchments in the Sierra Nevada: susceptibility to acidification. Final Report, California Air Resources Board, Contract A032-188.

Morris, D. P., \& Lewis, W. M., Jr. (1988). Phytoplankton nutrient limitation in Colorado mountain lakes. Freshwater Biology, 20, 315-327.

NADP/NTN (National Atmospheric Deposition Program/National Trends Network), 2009. (http://nadp.sws.uiuc.edu).

Nanus, L., Campbell, D. H., Ingersoll, G. P., Clow, D. W., \& Mast, M. A. (2003). Atmospheric deposition maps for the Rocky Mountains. Atmospheric Environment, 37, 4881-4892.

Nanus, L., Williams, M. W., Campbell, D. H., Tonnessen, K. A., Blett, T., \& Clow, D. W. (2009). Assessment of lake sensitivity to acidic deposition in national parks of the Rocky Mountains. Ecological Applications, 19, 961-973.

Oldfield, F., \& Appleby, P. G. (1984). Empirical testing of ${ }^{210} \mathrm{~Pb}$-dating models for lake sediments. In E. Y. Haworth 
\& J. W. G. Lund (Eds.), Lake sediments and environmental history (pp. 93-124). Minneapolis: University of Minnesota Press.

Pederson, G. T., Graumlich, L. J., Fagre, D. B., Kipfer, T., \& Muhlfeld, C. C. (2009). A century of climate and ecosystem change in western Montana: what do temperature trends portend? Climatic Change. doi:10.1007/ s10584-009-9642-y.

Porter, E., Blett, T., Potter, D., \& Huber, C. (2005). Protecting resources on federal lands: implications of critical loads for atmospheric deposition of nitrogen and sulfur. Bioscience, 55, 603-612.

Rühland, K., Paterson, A. M., \& Smol, J. P. (2008). Hemispheric-scale patterns of climate-related shifts in planktonic diatoms from North American and European lakes. Global Change Biology, 14, 2740-2754.

Saros, J. E., Interlandi, S. J., Wolfe, A. P., \& Engstrom, D. R. (2003). Recent changes in the diatom community structure of lakes in the Beartooth Mountain Range, USA. Arctic, Antarctic and Alpine Research, 35, 18--25.

Saros, J. E., Michel, T. J., Interlandi, S. J., \& Wolfe, A. P. (2005). Resource requirements of Asterionella formosa and Fragilaria crotonensis in oligotrophic alpine lakes: implications for recent phytoplankton community reorganizations. Canadian Journal of Fisheries and Aquatic Sciences, 62, 1681-1689.

Saros, J.E., Rose, K.C., Clow, D.W., Stephens, V.C., Nurse, A. B., Arnett, H.A., Stone, J.S., Williamson, C.E., \& Wolfe,
A.P. (2010). Melting alpine glaciers enrich high-elevation lakes with reactive nitrogen. Environmental Science \& Technology. doi:10.1021/es100147j.

Schlesinger, W. H. (2009). Thresholds risk prolonged degradation. Nature Reports Climate Change, 3, 112-113.

Smith, R. A., Alexander, R. B., \& Schwartz, G. E. (2003). Natural background concentrations of nutrients in streams and rivers of the conterminous United States. Environmental Science \& Technology, 37, 3039-3047.

Smol, J. P., et al. (2005). Climate-driven regime shifts in the biological communities of arctic lakes. Proceedings of the National Academy of Science, 102, 4397-4402.

Whiting, M. C., Whitehead, D. R., Holmes, R. W., \& Norton, S. A. (1989). Paleolimnological reconstruction of recent acidity changes in four Sierra Nevada lakes. Journal of Paleolimnology, 2, 285-304.

Winder, M., Reuter, J. E., \& Schladow, S. G. (2009). Lake warming favours small-sized planktonic diatom species. Proceedings of the Royal Society B, 276, 427-435.

Wolfe, A. P., Baron, J. S., \& Cornett, R. J. (2001). Anthropogenic nitrogen deposition induces rapid ecological changes in alpine lakes of the Colorado Front Range (USA). Journal of Paleolimnology, 25, 1-7.

Wolfe, A. P., Van Gorp, A. C., \& Baron, J. S. (2003). Recent ecological and biogeochemical changes in alpine lakes of Rocky Mountain National Park (Colorado, USA): A response to anthropogenic nitrogen deposition. Geobiology, $1,153-168$. 